\title{
Effects of volunteerism and relationship status on empathy
}

\section{Melissa Milanovic}

Department of Psychology, College of Social and Applied Human Sciences, University of Guelph, Guelph, ON Canada. Faculty supervisor: Jeffrey Spence. For correspondence, please email: milanovmelissa@gmail.com.

\section{Abstract}

Volunteerism and relationship status differences were examined for their relatedness to empathy level, in the context of a psychological instrument for measuring empathy, the Baron-Cohen and Wheelwright Empathy Quotient (EQ). This Likerttype scale consisting of 60 items was completed by each of $\mathbf{1 0 0}$ participants, who were categorized based on self-declared volunteerism (a volunteer or not) and relationship status (in a relationship or not). Volunteerism was found to be a statistically significant factor in empathy level: those who volunteered exhibited higher empathy levels than those who did not. Relationship status was additionally statistically significant, such that those in a relationship had higher empathy levels than those who were not. When analyzed together, the factors of volunteerism and relationship status showed significant interaction in their influence on the dependent variable, empathy.

Keywords: volunteerism; relationship status; empathy

\section{Introduction}

By definition, empathy is the ability to understand and share another person's emotion while being sensitive to their thoughts and feelings [1]. It additionally entails an appropriate affective response by the observer to the other individual's mental state. In a cognitive sense, being capable of empathic expression involves being able to understand how another person is feeling, and responding to this nonegocentrically $[2,3]$. The capacity to be empathic, or to express empathy, ultimately allows one to understand the behaviours and feelings of others and predict their behaviour. Hence, it allows effective interaction within a social context.

By nature, humans are social beings. Our lives are primarily influenced by interactions with others, and the concern that we hold for others plays an important role in the course of our interactions and relationships with them. Empathy is a behaviour exhibited consistently by few individuals because it requires looking outside of oneself and focusing on what another person is experiencing. In a world of frequent competition for money, jobs, and opportunities, it is often difficult to forget about our own needs and instead focus our efforts on another.

Thus, it may be useful to delve into the roots of empathy, and determine factors that are correlated with higher levels of empathy. With this knowledge, individuals might be better able to predict how their actions might affect others and work towards better understanding the thoughts and feelings of those around them.

\section{Behaviours related to empathy}

Certain circumstances or experiences may be related to the extent to which an individual is empathic. The present study was developed with the intent of investigating two such important factors, relationship status and volunteerism, and how they correlate with the way that individuals behave towards others. Relationship status is expected to be correlated with empathic behaviour, because being in a committed relationship with another individual requires consideration for their thoughts and feelings and a desire to care for their wellbeing. Similarly, given that volunteers are individuals who willingly devote their time to aiding others without monetary compensation, those who elect to be volunteers may demonstrate more empathic behaviour. Thus, both volunteerism and relationship status are hypothesized correlates of empathy.

\section{Background and literature review}

There are varying degrees of volunteerism, but research has found some concrete results pertaining to the connectedness of empathy and volunteerism. Wilhelm and Bekkers discovered that individuals who express high levels of empathic concern have particularly high levels of helping behaviour [4]. In line with this conclusion is evidence presented by Roberts and Strayer, which states that empathy 
is an important contributor to prosocial behaviour, defined as voluntary behaviour intended to benefit another with no goal other than to help fellow humans [5]. It thus appears that higher levels of empathy are correlated with one's likelihood of engaging in activities, such as volunteering, that seek to aid other individuals without material gain.

It is further postulated that being in a relationship affects empathic expression. One particular investigation found that people who are married are more likely to volunteer than their single counterparts [6]. Additional research has demonstrated that individuals are generally more likely to volunteer for a cause if they are in a committed relationship, regardless of their sex [7]. This, in addition to findings by Roberts and Strayer suggests that individuals in relationships exhibit more empathic and prosocial behaviour and are thus driven towards volunteer roles [5]. This postulation could be probable, were it not for contradicting results presented by Stolinski and colleagues [8]. In particular, they discovered that participants, who were volunteers, were driven to engage in volunteer roles because of the challenge it presented and the importance that they felt that role possessed. This leads to the question of whether individuals engage in volunteer work for the challenge is presents, or for reasons associated with empathy. Perhaps individuals in relationships do show more empathic concern, but whether this shows correlation with greater volunteerism among such individuals remains ambiguous. Thus, uncertainty remains in regard to whether being in a relationship and partaking in volunteerism are significantly related to one's empathy level.

\section{Objectives}

The present study was developed with the intention of adding to previous literature in the area of empathy and the factors that are related to its exhibition. A comparison of empathy levels between those in a relationship and those not, as well as between those who are volunteers and those who are not, is needed to see whether empathy is related to each factor. In the present research, empathy is measured using the Baron-Cohen and Wheelwright Empathy Quotient (EQ) [1] (Appendix 1).

Three hypotheses are postulated. Primarily, it is hypothesized that there will be a correlation between volunteerism and empathy, such that individuals who are volunteers will exhibit higher empathy levels than those who are not volunteers. Further, it is hypothesized that there will be a correlation between relationship status and empathy, such that individuals who are in a relationship will exhibit higher levels of empathy than those who are not. Finally, an interaction effect is hypothesized, such that those who are both in a relationship and are volunteers will have the highest overall level of empathy.

\section{Methods}

\section{Participants}

Empathy level was measured for a set of participants $\left(N=100, M_{\text {age }}=20.880, S D_{\text {age }}=1.328\right.$, age range: $18-26)$, including both males $(n=46)$ and females $(n=54)$. All participants came from the population of students attending the University of Guelph. Thus, the participant sample was a convenience sample, recruited directly by the researcher. All participants completed the Empathy Quotient in its entirety.

\section{Materials}

The materials consisted of a booklet containing the Empathy Quotient. After completing the EQ via pen and paper, participants declared their volunteer status (whether they were a volunteer or not) and relationship status (whether they were in a relationship or not) by check box format. Additionally, demographic information at the end of the booklet asked participants to provide their age and sex. As such, participants assigned themselves into one of four categories: in a relationship and a volunteer, in a relationship and not a volunteer, not in a relationship and a volunteer, and not in a relationship and not a volunteer.

\section{The Empathy Quotient}

The Empathy Quotient (EQ), created by BaronCohen and Wheelwright was used as the measurement tool to assess empathy for each participant [1]. The EQ consisted of 60 questions, 40 of which measured empathy, and 20 of which were filler items. Examples of items that assessed empathy were, "I really enjoy caring for other people", and "I am good at predicting how someone will feel". An example of a filler question was "I am at my best first thing in the morning". The filler items were simply included to avoid a continuous focus on empathy-related items, and to reduce the testing threat to internal validity.

The EQ was a Likert-formatted scale, and thus respondents had the option to respond to each item with one of four responses, including "strongly agree", "slightly agree", "slightly disagree", and "strongly disagree". Approximately half of the empathy-based items were worded to produce a "disagree" response, and half to produce an "agree" response towards empathy, to avoid response bias. To account for this, reverse scoring was used on half of the items.

The Empathy Quotient was selected primarily for its reliability in assessing empathy. Previous literature provided a reliability of $r=0.97$ for the EQ [1]. Additionally, it was selected for its straightforward scoring scheme since the individual EQs were hand-scored (refer to Appendix 2 for scoring rules). 
Procedure

Data collection occurred over a period of approximately two weeks in calm, relatively private areas with minimal distractions. A standardized description of the research was presented to each participant to ensure consistent and standardized interaction between the participant and researcher. Upon receiving informed consent from each participant, the researcher gave all of them a package containing the EQ scale, demographic information, and self-declaration check boxes for relationship status and volunteerism. Since participants were self-assigned into the conditions of relationship status and volunteerism, the design takes the classification of non-experimental.

Upon completion of the package, participants were each debriefed, and any concluding questions were answered. Participants did not receive any form of compensation for participation. Completed surveys were maintained in a safe, private location until all data were collected. Once data was collected from all 100 participants, all EQs were hand-scored, and the data were entered into a master SPSS file for appropriate analyses.

\section{Results}

Analyses focused on each participant's overall empathy level score. A two-way between subjects factorial Analysis of Variance (ANOVA) was used. Although it was hoped that the ANOVA assumption of groups having the same sample size would be met, numbers were slightly unequal in two of the four conditions. Refer to Appendix 3 for the sample size and descriptive statistics for each condition.

A Levene's Test of Equality of Error Variances was conducted to assess the assumption that the error variances of the dependent variable (empathy score) was equal across groups. The Levene's Test value was significant, and as such, the null hypothesis of equality of error variances was not accepted, $F(3,96)=3.884, p=0.011$. Since the resulting significance value of Levene's Test was below the critical value of 0.05 , the obtained differences in sample variances was unlikely to have occurred based on random sampling. As such, a difference exists between the variances in the population. This finding is not unreasonable considering a non-experimental design was used, and by definition, that entails that samples were not randomly selected. Since the equality of error variances is an assumption of ANOVA, caution must be exercised in interpreting the results obtained.

\section{Volunteering and empathy}

The first hypothesis $\left(\mathrm{H}_{1}\right)$ stated that individuals who were volunteers would exhibit higher levels of empathy than those who were not volunteers, thus indicating a correlation between volunteerism and empathy. Data analysis showed a significant correlation between volunteerism and empathy, such that those who reported being volunteers had significantly higher empathy scores than those who were not volunteers, $F(1,94)=6.988, p=0.010, \eta_{\mathrm{p}}{ }^{2}=0.069$. Observed power was 0.744 . For volunteers, $M=47.369, S E=2.178$ and for non-volunteers, $M=38.854, S E=2.077$. Therefore, the first proposed hypothesis $\left(\mathrm{H}_{1}\right)$ was not rejected.

\section{Relationship status and empathy}

The second hypothesis $\left(\mathrm{H}_{2}\right)$ stated that individuals who were in a relationship would exhibit higher levels of empathy than those who were not in a relationship, thus indicating a correlation between being in a relationship and empathy. Data analysis showed a significant correlation between relationship status and empathy, such that those who reported being in a relationship had significantly higher empathy scores than those who were not in a relationship, $F(1,94)=$ 4.795, $p=0.031, \eta_{\mathrm{p}}{ }^{2}=0.049$. Observed power was 0.582 . For those in a relationship, $M=46.328, S E=2.028$ and for those not, $M=39.895, S E=2.017$. Thus, the second proposed hypothesis $\left(\mathrm{H}_{2}\right)$ was not rejected.

\section{Volunteerism and relationship status on empathy}

The third hypothesis $\left(\mathrm{H}_{3}\right)$ predicted an interaction effect between volunteerism and relationship status, such that those who were volunteers and in a relationship would have a higher overall level of empathy than all other groups. A significant interaction effect between volunteerism and relationship status was found, $F(1,94)=4.448, p=0.038$, $\eta_{\mathrm{p}}{ }^{2}=0.045$. Observed power was 0.551 . Specifically, the empathy level of those who were volunteers and in a relationship $(M=53.554, S E=3.012)$ was significantly higher than those who were volunteers and not in a relationship $(M=41.185, S E=2.943)$, those who were not volunteers and were in a relationship $(M=39.101, S E=$ $2.813)$, and those who were not volunteers and were not in a relationship $(M=38.606, S E=3.004)$ (Figure 1 , Appendix 3). Thus, the third proposed hypothesis $\left(\mathrm{H}_{3}\right)$ was not rejected.

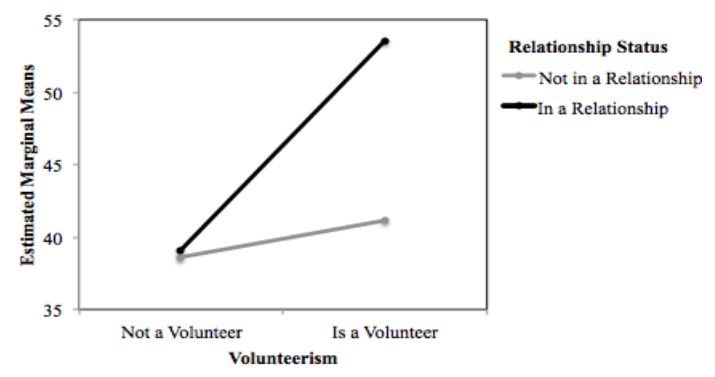

Figure 1. Plot detailing volunteerism by relationship status. Note the absence of parallelism between both interaction slopes, which clearly displays the significant interaction between the factors. 


\section{Item analyses}

Item analyses were conducted on the data obtained from the 100 Empathy Quotients as completed by participants. Specifically, the 40 items that measured empathy were analyzed for internal consistency, and the resulting reliability was strong $(\alpha=0.944)$. As such, it is fair to conclude that the 40 items assessed the same construct as the entire test to a high degree. The distribution of total empathy scores obtained by each participant approached a normal distribution. The maximum possible empathy score an individual could receive on the EQ was 80 , and the minimum possible score was zero. The sample results indicated a mean total empathy score of 43.060 , and standard deviation of 16.549. As such, the majority of total empathy scores clustered around the central range of possible scores and the standard deviation provided indication of an acceptable variance in the scores (Figure 2).

It should again be noted that Levene's Test of Equality of Error Variances was significant, and as such, the ANOVA assumption of equality of error variances between groups was not met. Although ANOVA is a relatively robust measure of analysis and all proposed hypotheses attained statistical significance, one should not uncritically assume their correctness without noting the lack of equality of error variance.

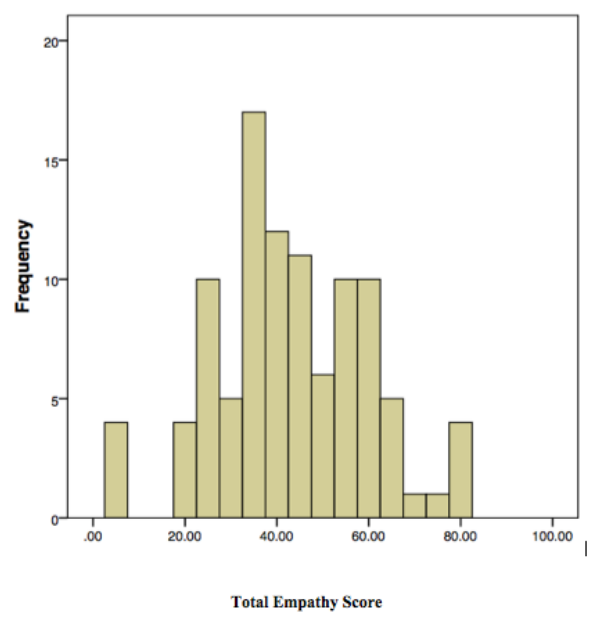

Figure 2. Histogram detailing the frequency of participants who obtained each of the possible scores, erected over discrete range intervals pertaining to the measure of empathy score, the Empathy Quotient (EQ).

\section{Discussion}

In the present study, volunteerism and relationship status were found to be correlated with empathy level, both individually and when considered together. In line with previous research, it was discovered that those who volunteer have higher levels of empathy than those who do not $[4,5]$.
Additionally, the finding that those in relationships exhibit higher levels of empathy than those who are not is also consistent with the literature [6,7].

The findings of Stolinski and colleagues brought upon a debate of whether the choice to volunteer is caused by higher levels of empathy, or if it is perhaps based on a separate factor such as the motivation to work through the challenges brought on by volunteering [8]. The present study found compelling evidence that there is indeed a link between volunteerism, relationship status, and empathy. However, this evidence does not preclude the possibility that other variables may be involved in the relationship between volunteerism and empathy, such as those discussed by Stolinski and colleagues [8]. Rather, it has contributed to the growing body of literature in this field. Specifically it has provided further evidence in addition to previous research that empathy likely plays a role in one's decision to volunteer, or that volunteering instills empathy. Further, results of the present research provide evidence in line with previous investigation that people in relationships express higher levels of empathy, or that empathic people tend to be in relationships, which could result in their greater seeking of volunteer roles.

\section{Practical implications}

In a world where empathic expression can sometimes be lacking, learning from those who are more likely to express it is an important tool in increasing our general knowledge on how to better demonstrate empathy. Since this research has determined sub-groups of people who show enhanced empathy, we can look towards further studying them. In particular, learning about their motives and underlying intentions for being attentive to the feelings of others might be a useful extension of this study.

In terms of real world examples of who would benefit from those with higher levels of empathy, one should consider individuals with abusive tendencies. Abusers, or those who show abusive tendencies at an early age, might learn from the proper demonstration of empathy, and from the teachings of those who have been found to possess higher levels of empathy. In addition, encouraging these individuals to partake in activities that are correlated with higher levels of empathy, for example volunteering, could serve as a beneficial tool in remediation programs or correctional facilities. Thus, a better understanding of who in our society might be more empathic would aid in helping those who show consistent low regard for the thoughts and feelings of others. Additional real life implications of this research could be to use the findings to aid in selecting the best-suited individuals for tasks or jobs that require high levels of empathy (e.g. helping professions such as doctors or nurses).

Research by Loran and colleagues revealed that people tend to underestimate the severity of others' social pain, and the effect that ostracism has on others [9]. Further analysis of the sub-groups (that were determined in the present study to be substantially high in empathy level) could 
provide more insight into whether empathy is a learned trait or if it is in part hereditary. In the event that empathy is acquired at least in part through learned behaviours, studies could examine what methods are the most effective in teaching individuals to be considerate of others. This is particularly relevant in settings where bullying is of concern; for example, in middle schools and high schools, students could benefit from workshops and extra discussion aimed at developing their consideration for the feelings of others.

\section{Theoretical implications}

In a theoretical sense, extending our knowledge about the basis of empathy will help in our understanding of why humans are motivated to help and care for others. Psychological altruism is a motivation state with the ultimate goal of increasing the welfare of others [10]. As such, altruism is an important component for enhancing the survival of another. Having pointed out particular groups of individuals who appear to be significantly more empathetic, the world of altruism is at our fingertips to further explore. While examining the precise evolutionary implications of altruistic behaviour might be a stretch beyond what is possible within the scope of this research, it is ultimately the improvement in our understanding of empathy and our ability to express it and care for others that can in the long run help us enhance survival of others.

\section{Strengths}

The study provided evidence in favour of the three proposed hypotheses, and as such, an improved general understanding of situations in which individuals might be more likely to show empathy has resulted.

Despite using a non-experimental design, the resulting sample size (determined through self-declaration) of each of the four conditions was almost a perfect split of the one hundred participants. Having as close to equal number of participants per condition as possible enhances power, or the ability to detect effects when they do exist.

Effect size is a measure of the difference that exists between groups. Cohen describes a general rule that one does not want an effect size below 0.2 [11]. The present study managed to obtain an effect size greater than this in all tests of hypotheses; a fair extent of the variability between the groups of the study can be explained by their true differences. Furthermore, the power of each test of between subjects is acceptable. Each test's power surpasses the level of chance, and therefore the likelihood of detecting an effect when there truly is one is greater than the likelihood of committing a type II error (otherwise stated as finding an effect when it actually does not exist) in all three tests.

\section{Limitations}

Like most non-experimental designs, limitation lies in the lack of random assignment of individuals to conditions. As such, a selection threat to internal validity results and it is difficult to prove equality among groups that are self-assigned. This research specifically lacks proof for the assumption of equal error variances between the groups and as such, all further results needed cautionary treatment. In order to truly assess whether the effects are statistically significant, a more robust analysis such as the BrownForsythe test (which is recommended as a robust measure for non-normal data) might be considered, in order to determine if statistical significance remains. Further limitation results from the restricting effect that a small sample size of one hundred participants places on the power and effect size. In order to have the most effective analysis and obtain the best results possible, a large sample size is of great importance. Additionally, instrumentation effects (a threat to internal validity) might have had an effect on results. In particular, the EQ is rather long, and instrumentation effects pertaining to being tired might have affected the respondents' performances.

The present study used a method of self-report data. This introduces the possibility of response bias, which could consequently alter proper observation of effects. Further, the declarations of relationship status and volunteerism were rather ridged, allowing for only one of two possible declarations: in a relationship/not in a relationship and volunteer/not a volunteer. As such, it does not allow for more specific relationship- and volunteer-based analysis. Perhaps individuals in differing types of volunteer positions differ in their empathy levels. Or, perhaps there is a difference in empathy between those in more casual versus long-term relationships. Thus, the ridged definitions of relationship status and volunteerism used in this research prohibit the investigation of more in-depth analyses of varying levels of each factor.

\section{Future research}

Future research along the same lines as the present study should consider increasing sample size, as it would increase the relevancy of the results obtained. In addition, further research might take the effects of relationship type, length or commitment level on empathy into consideration. Perhaps individuals in marital versus casual relationships would have significant differences in empathy level, and research into such specifics would improve knowledge regarding the factors that underlie empathy. Furthermore, in this research, it was decided not to assess the effect of sex on empathy due to compelling results presented by Hill and colleagues that sex does not have particular effects on empathy [7]. Despite this, additional research that 
incorporates the effect of sex on empathy might be of use in further confirming or debating Hill and colleagues' conclusion.

Finally, on a neurobiological level, there may be certain areas of the brain or brain pathways that are implicated in the existence, development, or maintenance of empathic behaviour. Research into the neurological aspects of empathy would provide a more empirical analysis. Such investigation might further the research in the present paper by investigating whether there are areas of the brain that are particularly active in individuals who are in relationships or are volunteers, and whether these areas are linked to regions of the brain known to be involved in the empathetic response.

To conclude, the present study has determined two subgroups of individuals who exhibit higher levels of empathy: individuals who are volunteers, and individuals who are in a relationship. As such, the potential to gain more insight into empathy through further analysis of these individuals has been revealed. The discoveries made up to this point regarding empathy should be acknowledged, and future attempts made to expand upon the understanding of factors and mechanisms that underlie empathy.

\section{References}

1. Baron-Cohen, S., \& Wheelwright, S. (2004). The Empathy Quotient: An investigation of adults with Asperger's Syndrome or high functioning autism, and normal sex differences. Journal of Autism and Developmental Disorders, 34(2), 163-175.

2. Kohler, W. (1929). Gestalt psychology. New York: Liveright.

3. Piaget, J. (1932). The moral judgment of the child. London: Routledge \& Kegan Paul.

4. Wilhelm, M. O., \& Bekkers, R. (2010). Helping behaviour, dispositional empathic concern, and the principle of care. Social Psychology Quarterly, 73(1), 11-32.

5. Roberts, W., \& Strayer, J. (1996). Empathy, emotional expressiveness, and prosocial behaviour. Child Development, 67, 449-470.

6. Sundeen, R. A. (1990). Family life course status and volunteer behaviour: implications for the single parent. Sociological Perspectives, 33(4), 483-500.

7. Hill, C. T., Rubin, Z., Peplau, L. A., \& Willard, S. G. (1979). The volunteer couple: sex differences, couple commitment, and participation in research on interpersonal relationships. Social Psychology Quarterly, 42(4), 415 - 420.

8. Stolinski, A. M., Ryan, C. S., Hausmann, L. R. M., \& Wernli, M. A. (2004). Empathy, guilt, volunteer experiences, and intentions to continue volunteering among buddy volunteers in an AIDS organization. Journal of Applied Biobehavioural Research, 9(1), $1-22$.

9. Loran, F. N., Banas, K., \& MacDonald, G. (2011). Empathy gaps for social pain: why people underestimate the pain of social suffering. Journal of Personality and Social Psychology, 100(1), 120128.

10. Batson, C. D., \& Moran, T. (1999). Empathyinduced altruism in a prisoner's dilemma. European Journal of Social Psychology, 29(7), 909-924.

11. Cohen, J. (1988). Statistical Power Analysis for the Behavioural Sciences. Hillsdale, NJ: Erlbaum. 


\section{Appendix 1}

The Baron-Cohen and Wheelwright Empathy Quotient (EQ)

Below is a list of statements. Please read each statement carefully and rate how strongly you agree or disagree with it by circling your answer. There are no right or wrong answers, or trick questions.

\begin{tabular}{|c|c|c|c|c|}
\hline 1. I can easily tell if someone else wants to enter a conversation. & strongly agree & slightly agree & slightly disagree & $\begin{array}{l}\text { strongly } \\
\text { disagree }\end{array}$ \\
\hline 2. I prefer animals to humans. & strongly agree & slightly agree & slightly disagree & $\begin{array}{l}\text { strongly } \\
\text { disagree }\end{array}$ \\
\hline 3. I try to keep up with the current trends and fashions. & strongly agree & slightly agree & slightly disagree & $\begin{array}{l}\text { strongly } \\
\text { disagree }\end{array}$ \\
\hline $\begin{array}{l}\text { 4. I find it difficult to explain to others things that I understand easily, when they } \\
\text { don't understand it the first time. }\end{array}$ & strongly agree & slightly agree & slightly disagree & $\begin{array}{l}\text { strongly } \\
\text { disagree }\end{array}$ \\
\hline 5. I dream most nights. & strongly agree & slightly agree & slightly disagree & $\begin{array}{l}\text { strongly } \\
\text { disagree }\end{array}$ \\
\hline 6. I really enjoy caring for other people. & strongly agree & slightly agree & slightly disagree & $\begin{array}{l}\text { strongly } \\
\text { disagree }\end{array}$ \\
\hline 7. I try to solve my own problems rather than discussing them with others. & strongly agree & slightly agree & slightly disagree & $\begin{array}{l}\text { strongly } \\
\text { disagree }\end{array}$ \\
\hline 8. I find it hard to know what to do in a social situation. & strongly agree & slightly agree & slightly disagree & $\begin{array}{l}\text { strongly } \\
\text { disagree }\end{array}$ \\
\hline 9. I am at $m y$ best first thing in the morning. & strongly agree & slightly agree & slightly disagree & $\begin{array}{l}\text { strongly } \\
\text { disagree }\end{array}$ \\
\hline $\begin{array}{l}\text { 10. People often tell me that I went too far in driving my point home in a } \\
\text { discussion. }\end{array}$ & strongly agree & slightly agree & slightly disagree & $\begin{array}{l}\text { strongly } \\
\text { disagree }\end{array}$ \\
\hline 11. It doesn't bother me too much if I am late meeting a friend. & strongly agree & slightly agree & slightly disagree & $\begin{array}{l}\text { strongly } \\
\text { disagree }\end{array}$ \\
\hline $\begin{array}{l}\text { 12. Friendships and relationships are just too difficult, so I tend not to bother } \\
\text { with them. }\end{array}$ & strongly agree & slightly agree & slightly disagree & $\begin{array}{l}\text { strongly } \\
\text { disagree }\end{array}$ \\
\hline 13. I would never break a law, no matter how minor. & strongly agree & slightly agree & slightly disagree & $\begin{array}{l}\text { strongly } \\
\text { disagree }\end{array}$ \\
\hline 14. I often find it difficult to judge if something is rude or polite. & strongly agree & slightly agree & slightly disagree & $\begin{array}{l}\text { strongly } \\
\text { disagree }\end{array}$ \\
\hline $\begin{array}{l}\text { 15. In a conversation, I tend to focus on my own thoughts rather than on what } \\
\text { my listener might be thinking. }\end{array}$ & strongly agree & slightly agree & slightly disagree & $\begin{array}{l}\text { strongly } \\
\text { disagree }\end{array}$ \\
\hline 16. I prefer practical jokes to verbal humor. & strongly agree & slightly agree & slightly disagree & $\begin{array}{l}\text { strongly } \\
\text { disagree }\end{array}$ \\
\hline 17. I live life for today rather than the future. & strongly agree & slightly agree & slightly disagree & $\begin{array}{l}\text { strongly } \\
\text { disagree }\end{array}$ \\
\hline 18. When I was a child, I enjoyed cutting up worms to see what would happen. & strongly agree & slightly agree & slightly disagree & $\begin{array}{l}\text { strongly } \\
\text { disagree }\end{array}$ \\
\hline 19. I can pick up quickly if someone says one thing but means another. & strongly agree & slightly agree & slightly disagree & $\begin{array}{l}\text { strongly } \\
\text { disagree }\end{array}$ \\
\hline 20. I tend to have very strong opinions about morality. & strongly agree & slightly agree & slightly disagree & $\begin{array}{l}\text { strongly } \\
\text { disagree }\end{array}$ \\
\hline 21. It is hard for me to see why some things upset people so much. & strongly agree & slightly agree & slightly disagree & $\begin{array}{l}\text { strongly } \\
\text { disagree }\end{array}$ \\
\hline 22. I find it easy to put myself in somebody else's shoes. & strongly agree & slightly agree & slightly disagree & $\begin{array}{l}\text { strongly } \\
\text { disagree }\end{array}$ \\
\hline $\begin{array}{l}\text { 23. I think that good manners are the most important thing a parent can teach } \\
\text { their child }\end{array}$ & strongly agree & slightly agree & slightly disagree & $\begin{array}{l}\text { strongly } \\
\text { disagree }\end{array}$ \\
\hline 24. I like to do things on the spur of the moment. & strongly agree & slightly agree & slightly disagree & $\begin{array}{l}\text { strongly } \\
\text { disagree }\end{array}$ \\
\hline 25. I am good at predicting how someone will feel. & strongly agree & slightly agree & slightly disagree & $\begin{array}{l}\text { strongly } \\
\text { disagree }\end{array}$ \\
\hline $\begin{array}{l}\text { 26. I am quick to spot when someone in a group is feeling awkward or } \\
\text { uncomfortable. }\end{array}$ & strongly agree & slightly agree & slightly disagree & $\begin{array}{l}\text { strongly } \\
\text { disagree }\end{array}$ \\
\hline $\begin{array}{l}\text { 27. If I say something that someone else is offended by, I think that that's their } \\
\text { problem, not mine. }\end{array}$ & strongly agree & slightly agree & slightly disagree & $\begin{array}{l}\text { strongly } \\
\text { disagree }\end{array}$ \\
\hline $\begin{array}{l}\text { 28. If anyone asked me if I liked their haircut, I would reply truthfully, even if I } \\
\text { didn't like it. }\end{array}$ & strongly agree & slightly agree & slightly disagree & $\begin{array}{l}\text { strongly } \\
\text { disagree }\end{array}$ \\
\hline 29. I can't always see why someone should have felt offended by a remark. & strongly agree & slightly agree & slightly disagree & $\begin{array}{l}\text { strongly } \\
\text { disagree }\end{array}$ \\
\hline 30. People often tell me that I am very unpredictable. & strongly agree & slightly agree & slightly disagree & $\begin{array}{l}\text { strongly } \\
\text { disagree }\end{array}$ \\
\hline 31. I enjoy being the center of attention at any social gathering. & strongly agree & slightly agree & slightly disagree & $\begin{array}{l}\text { strongly } \\
\text { disagree }\end{array}$ \\
\hline 32. Seeing people cry doesn't really 4 & strongly agree & slightly agree & slightly disagree & $\begin{array}{l}\text { strongly } \\
\text { disagree }\end{array}$ \\
\hline
\end{tabular}


Effects of volunteerism and relationship status on empathy (Milanovic)

\begin{tabular}{|c|c|c|c|c|}
\hline 33. I enjoy having discussions about politics. & strongly agree & slightly agree & slightly disagree & $\begin{array}{l}\text { strongly } \\
\text { disagree }\end{array}$ \\
\hline $\begin{array}{l}\text { 34. I am very blunt, which some people take to be rudeness, even though this is } \\
\text { unintentional. }\end{array}$ & strongly agree & slightly agree & slightly disagree & $\begin{array}{l}\text { strongly } \\
\text { disagree }\end{array}$ \\
\hline 35. I don't tend to find social situations confusing. & strongly agree & slightly agree & slightly disagree & $\begin{array}{l}\text { strongly } \\
\text { disagree }\end{array}$ \\
\hline $\begin{array}{l}\text { 36. Other people tell me I am good at understanding how they are feeling and } \\
\text { what they are thinking. }\end{array}$ & strongly agree & slightly agree & slightly disagree & $\begin{array}{l}\text { strongly } \\
\text { disagree }\end{array}$ \\
\hline $\begin{array}{l}\text { 37. When I talk to people, I tend to talk about their experiences rather than my } \\
\text { own. }\end{array}$ & strongly agree & slightly agree & slightly disagree & $\begin{array}{l}\text { strongly } \\
\text { disagree }\end{array}$ \\
\hline 38. It upsets me to see an animal in pain. & strongly agree & slightly agree & slightly disagree & $\begin{array}{l}\text { strongly } \\
\text { disagree }\end{array}$ \\
\hline 39. I am able to make decisions without being influenced by people's feelings. & strongly agree & slightly agree & slightly disagree & $\begin{array}{l}\text { strongly } \\
\text { disagree }\end{array}$ \\
\hline 40. I can't relax until I have done everything I had planned to do that day. & strongly agree & slightly agree & slightly disagree & $\begin{array}{l}\text { strongly } \\
\text { disagree }\end{array}$ \\
\hline 41. I can easily tell if someone else is interested or bored with what I am saying. & strongly agree & slightly agree & slightly disagree & $\begin{array}{l}\text { strongly } \\
\text { disagree }\end{array}$ \\
\hline 42. I get upset if I see people suffering on news programs. & strongly agree & slightly agree & slightly disagree & $\begin{array}{l}\text { strongly } \\
\text { disagree }\end{array}$ \\
\hline $\begin{array}{l}\text { 43. Friends usually talk to me about their problems as they say that I am very } \\
\text { understanding. }\end{array}$ & strongly agree & slightly agree & slightly disagree & $\begin{array}{l}\text { strongly } \\
\text { disagree }\end{array}$ \\
\hline 44. I can sense if I am intruding, even if the other person doesn't tell me. & strongly agree & slightly agree & slightly disagree & $\begin{array}{l}\text { strongly } \\
\text { disagree }\end{array}$ \\
\hline $\begin{array}{l}45 . \text { I often start new hobbies but quickly become bored with them and move on to } \\
\text { something else. }\end{array}$ & strongly agree & slightly agree & slightly disagree & $\begin{array}{l}\text { strongly } \\
\text { disagree }\end{array}$ \\
\hline 46. People sometimes tell me that I have gone too far with teasing. & strongly agree & slightly agree & slightly disagree & $\begin{array}{l}\text { strongly } \\
\text { disagree }\end{array}$ \\
\hline 47. I would be too nervous to go on a big rollercoaster. & strongly agree & slightly agree & slightly disagree & $\begin{array}{l}\text { strongly } \\
\text { disagree }\end{array}$ \\
\hline 48. Other people often say that I am insensitive, though I don't always see why. & strongly agree & slightly agree & slightly disagree & $\begin{array}{l}\text { strongly } \\
\text { disagree }\end{array}$ \\
\hline $\begin{array}{l}\text { 49. If I see a stranger in a group, I think that it is up to them to make an effort to } \\
\text { join in. }\end{array}$ & strongly agree & slightly agree & slightly disagree & $\begin{array}{l}\text { strongly } \\
\text { disagree }\end{array}$ \\
\hline 50. I usually stay emotionally detached when watching a film. & strongly agree & slightly agree & slightly disagree & $\begin{array}{l}\text { strongly } \\
\text { disagree }\end{array}$ \\
\hline $\begin{array}{l}51 . \text { I like to be very organized in day-to-day life and often make lists of the chores I } \\
\text { have to do. }\end{array}$ & strongly agree & slightly agree & slightly disagree & $\begin{array}{l}\text { strongly } \\
\text { disagree }\end{array}$ \\
\hline 52. I can tune into how someone else feels rapidly and intuitively. & strongly agree & slightly agree & slightly disagree & $\begin{array}{l}\text { strongly } \\
\text { disagree }\end{array}$ \\
\hline 53. I don't like to take risks. & strongly agree & slightly agree & slightly disagree & $\begin{array}{l}\text { strongly } \\
\text { disagree }\end{array}$ \\
\hline 54. I can easily work out what another person might want to talk about. & strongly agree & slightly agree & slightly disagree & $\begin{array}{l}\text { strongly } \\
\text { disagree }\end{array}$ \\
\hline 55. I can tell if someone is masking their true emotion. & strongly agree & slightly agree & slightly disagree & $\begin{array}{l}\text { strongly } \\
\text { disagree }\end{array}$ \\
\hline 56. Before making a decision I always weigh up the pros and cons. & strongly agree & slightly agree & slightly disagree & $\begin{array}{l}\text { strongly } \\
\text { disagree }\end{array}$ \\
\hline 57. I don't consciously work out the rules of social situations. & strongly agree & slightly agree & slightly disagree & $\begin{array}{l}\text { strongly } \\
\text { disagree }\end{array}$ \\
\hline 58. I am good at predicting what someone will do. & strongly agree & slightly agree & slightly disagree & $\begin{array}{l}\text { strongly } \\
\text { disagree }\end{array}$ \\
\hline 59. I tend to get emotionally involved with a friend's problems. & strongly agree & slightly agree & slightly disagree & $\begin{array}{l}\text { strongly } \\
\text { disagree }\end{array}$ \\
\hline $\begin{array}{l}\text { 60. I can usually appreciate the other person's viewpoint, even if I don't agree with } \\
\text { it. }\end{array}$ & strongly agree & slightly agree & slightly disagree & $\begin{array}{l}\text { strongly } \\
\text { disagree }\end{array}$ \\
\hline
\end{tabular}




\section{Appendix 2}

\section{The Empathy Quotient Scoring Scheme}

Positively Worded Items

These items are stated in such a way that responding towards the "agree" end of the response scale indicates a higher level of empathy. "Strongly agree" responses score 2 points and "Slightly agree" responses score 1 point on these items: $1,6,19,22,25,35,36,37,38,41,42,43,44,52,54,55,57,58,59,60$. These items receive a score of zero if responded with "Strongly disagree" or "Slightly disagree" by the participant.

Negatively Worded Items

These items are stated in such a way that responding towards the "disagree" end of the response scale indicates a higher level of empathy. "Strongly disagree" responses score 2 points and "Slightly disagree" responses score 1 point for items: $4,8,10,11,12,14,15,18,21,27,28,29,32,34,39,46,48,49,50$. These items receive a score of zero if responded with "Strongly agree" or "Slightly agree" by the participant.

Filler Items

Filler items (items 2, 3, 5, 7, 9, 13, 16, 17, 20, 23, 24, 30, 31, 33, 40, 45, 47, 51, 53, and 56) are not scored, and thus do not contribute to overall empathy score.

Range of Total Scores

On each item, a participant can score a 0,1 , or 2 . This results in a maximum possible empathy score of 80 , and a minimum possible empathy score of zero.

\section{Appendix 3}

Participant between Subject Factors (Relationship Status and Volunteerism) Statistical Values

\begin{tabular}{|c|c|c|c|c|c|c|}
\hline \multirow[b]{2}{*}{ Relationship Status } & \multirow[b]{2}{*}{ Volunteerism } & \multirow[b]{2}{*}{$N$} & \multirow[b]{2}{*}{$M$} & \multirow[b]{2}{*}{$S E$} & \multicolumn{2}{|c|}{$95 \% \mathrm{Cl}$} \\
\hline & & & & & $L L$ & $U L$ \\
\hline \multirow[t]{2}{*}{ Not in a Relationship } & Not a Volunteer & 27 & 38.606 & 3.004 & 32.642 & 44.570 \\
\hline & Is a Volunteer & 23 & 41.185 & 2.943 & 35.342 & 47.028 \\
\hline \multirow[t]{2}{*}{ In a Relationship } & Not a Volunteer & 25 & 39.101 & 2.813 & 33.516 & 44.687 \\
\hline & Is a Volunteer & 25 & 53.554 & 3.012 & 47.574 & 59.534 \\
\hline
\end{tabular}

Note: $\mathrm{Cl}=$ confidence interval; $\mathrm{LL}=$ lower limit, $\mathrm{UL}=$ upper limit 